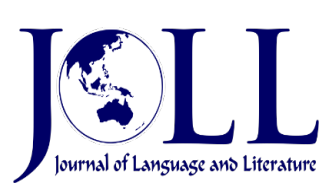

Vol. 21 No. 1, April 2021, pp. 190 - 197

DOI: 10.24071/joll.v21i1.3145

Available at https://e-journal.usd.ac.id/index.php/JOLL/index

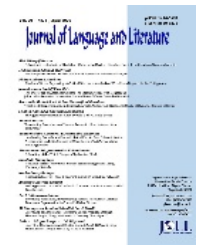

This work is licensed under a Creative Commons Attribution-ShareAlike 4.0 International License.

\title{
Finding God in All Things through Poetry
}

\author{
Novita Dewi \\ novitadewi@usd.ac.id \\ Graduate Program in English Language Studies, Sanata Dharma University, INDONESIA
}

\begin{abstract}
Poetry is a language of devotion. It is the melody that resonates from one's pure conscience. Being the most important and richest part of our spiritual practice, people read and write poems to help them gain understanding about

themselves, each other, and the world around them. Examining world poetry, mainly from America, Indonesia, and Sri Lanka which tell about the presence of God, this article attempts to find out how God the Creator is present and represented, focusing as it does on the connection between poetry and spiritual exercises. Each of the seven poems under discussion is read by considering Ignatian Spirituality of which the core is "Finding God in All Things". The selected poems show that God can indeed be found in three main spots. First, God resides in the universe. The presence of God in nature is a common theme shared by the poets discussed. Second, the speakers of the poems find God within themselves. They find God through discretion. Third, some of them find the face of God in that of other people because humans are created in His image. The poems open an awareness that God is present in the sufferings of others. In conclusion, poetry serves as a prayer and spiritual exercises that can improve people's inner compassion and justice.
\end{abstract}

Article

information

Received:

23 February

2021

Keywords: Ignatian Spirituality; poetry; prayer; spiritual exercises

\section{Introduction}

Sacred poetry of all religious traditions generally speaks of faith, that is, bringing the reader closer to the Divine. Poets of different faiths express their most profound gratitude to the Divine throughout the time. Studies on the relationship between poetry and spirituality have been abundant, especially about the great poets of diverse cultural and religious backgrounds: Jalāl ad-Dīn Muhammad Rūmī the Persian Sufi poet; the Chinese poet T'ao
Ch'ien known for his Buddhist teachings; Laotzu the philosopher with his Taoist poems, Vyasa with the epic Mahabharata; Christian poetry in the New Testament, and many more.

The relationship between literature and theology can also be seen in modern poetry inspired by diverse principles in the world's major religions. According to Kubarek, Islamic literature began to develop in the 1980s as a counterpoint to secular literature adopting both themes and traditions in the Western 
literary works (Kubarek, 2016). Besides containing moral teachings, poetry also embodies Islamic principles and creeds. Poetry also occupies an important position in the Confucian program and modern Chinese poetic thought (Han, 2013; Shen, 2014; Thompson \& Wei-Ming, 1987; YEH, 1988). Poets combine contents with the best form whereby the quality of the poems must be accompanied by moral qualities. Here the social effect of poetry is emphasized, namely the passion for the perfection of life and the highest good in classical education which was based on Confucianism. Poetry also played an important role in the political, diplomatic, and cultural spheres in ancient China. In one of his books, The Analects, Confucius reportedly told his son Bo $\mathrm{Yu}$ that people would not know what to say if they did not study poetry (YAN Xiao-jiang, 2017).

There have also been countless studies on the synergy between poetry and Christian spirituality from the classical to contemporary literary works around the world. Encounters with God in Medieval and Early Modern English Poetry, for example, provides a linguistic analysis of a few well-known poems in English literature (Besserman \& Clutterbuck, 2007). One of Clutterbuck's findings is the nature of dialogue with God in some sacred poems which has so far been neglected by linguistic and literary scholars. The religious poems Clutterbuck discussed include William Langland's "Piers Plowman" (Clutterbuck, 2018), John Donne's Divine Poems, and John Milton's famous "Paradise Lost" (McMahon, 2010).

Another monumental Christian religious literary work is George Herbert's The Temple published in 1633. This collection of poetry describes the reciprocal relationship between people and God. Herbert shows that human is the home of God's glory; and the human heart is where God resides (Hwang, 2018). Herbert is one of the classical poets whose works are often studied both literally and in dialogue between arts and theology, especially Christian faith. This Anglican priest at Salisbury Cathedral in the seventeenthcentury England is known as the most famous religious poet in English literature, partly because of the simplicity of his choice of diction and the use of metaphors in his poetry.

George Herbert's influence is seen in the contemporary poet and Anglican priest Malcolm Guite who published sonnets that neatly follow the liturgical calendar (Guite, 2011, 2017a, 2017b). Guite's newest collection of poems entitled After Prayer begins with a series of sonnets in response to Herbert's other famous poem "The Prayer". In an interview, this pastor, poet, and lecturer at Girton College, University of Cambridge acknowledged George Herbert's enormous influence on his creativity. Inspired by Herbert, Guite's poetry testifies as to how art and faith work together in his life. Guite's poems provide insight and connection to the Bible stories in new ways. He also wrote a few scientific studies on poetry and theology such as Faith, Hope and Poetry: Theology and the Poetic Imagination which has received much recognition and appreciation (Neumann, 2012; Richardson, 2013; Twombly, 2013).

Like Guite and the classical writers mentioned above, another contemporary writer, Shemaiah Gonzalez, argues that poetry is one of the many ways to find God. Gonzalez meets God in her daily life through the following four things. First, she calls it "touchstone" - an object that reminds us that God is here, with us, in a very personal way, for example through butterflies, flowers, leaves, trees, and so on (Gonzalez, n.d.). God is also present in the second hidden place which is the voice. Gonzalez has written numerous articles on silence but has come to realize that God is not only found in silence, but also in lingering noise, even crowds. The third place God is found is in the home when we are doing our daily work. Here, Gonzalez imitates St. Theresia from Lisieux who said that the presence of God is felt closest not at the time of prayer, but during her doing household chores. Gonzalez has also learned from her mother-inlaw who raised six children, but she was often heard singing while she was working. Even the smallest task can be of incarnational value and becomes a way to live and breathe God's love. Finally, this freelance writer from Los Angeles claims that poetry is the fourth place God can be found. Gonzalez found many sources of data on the intricacies of poetry. Gonzalez also 
discovered a long history of various poems from various parts of the world which turned into a means of finding God's presence.

Suffice it to say for now that contemplative works from time to time talk about people's (unique) experiences. It is important to discuss an encounter with God wrapped in a literary reality so that others can feel this seemingly personal experience. This article will discuss several poems from various countries that specifically talk about the presence of God. Amid hoax and hateful narratives as well as numerous information that further distance us from God's will, the presence of reflective-contemplative poetry is duly important and therapeutic. Poetry opens the complex dimensions of human freedom and intimate relationships with the Creator.

Reading or writing poetry is an important part of daily rituals that is naturally aspirational. Poetry is a language of devotion, the richest expression of a spiritual practice. Poetry is the echo of a pure inner voice. Poetry creates clarity, deepens, and expands continuous exploration into the deepest mysteries of life. In Poetry as Spiritual Practice, Robert McDowell says that every religious person, even an atheist, always looks for spirituality in her/his daily life whether consciously or not (McDowell, 2008). Everyone has a desire for peace and understanding. Through poetry, people gain peace and understanding of themselves, others, and the world around them. McDowell invites us to make poetry an important part of daily rituals, aspirations, and intentions in our quest for meaning, growth, and greater peace in life. Thus, for both readers and writers, poetry is beneficial because it generates wisdom, compassion, confidence, patience, and energy to show greater love for the Creator and His creations.

Next, the encounter with a loving God is at the heart of St. Ignasius de Loyola and his companions (Spirituality: Finding God in All Things, n.d.). Based on the belief that God is active in the real world, this spiritual path laid down by the founder of the Society of Jesus helps us discern God's presence, i.e., finding God in all things and reaching out to a diverse, gracious yet imperfect world. This spirituality is brought into a broader human context such as pursuing social justice, peace, and dialogue. Being contemplative in action means that our active life feeds the contemplative life; and our contemplative life provides information about active life. It is precisely where God is present. Activities to open ourselves to God and let Him enter into us completely are called spiritual exercises. These activities can be in the form of meditation, chanting prayers, keeping diaries, writing poetry, creating works of art, playing music, even taking a walk to enjoy nature as long as it has one single purpose, that is, to let God speak (George W. Traub, 2008). In a quiet inner situation, one can find God anywhere and at any time, just like St. Ignatius' ideal of finding God in everything and everything in God. The goal of this study is thus to identify God's presence in some selected contemporary poems. The research question is: In what ways the poets discover the existence of God in their respective poems that serve as prayers?

\section{Methodology}

The primary data used in this study were seven poems, i.e., "Nothing is Far". "Sajak tentang Kau", "Di Masjid Besar", "Misal", "Who Hides", "Kolam", and "Easter at Kentucky Fried Chicken". The secondary data were relevant journal articles and books to support the reading of the poems. Each poem was read using three simple steps introduced by Timpane (2001) that include getting the basic information, speculating the meaning, and interpreting the meaning. Firstly, the researcher obtained the lowest level of poetry reading by paraphrasing each poem to make meaning clearer. The second step was speculation: What does the poet mean? The second step was of great importance because it allowed readers (in this case, the researcher) grab the clearer meaning of each poem. The third step was interpretation. Here, the poem was read with Ignatian Spirituality, particularly "Finding God in All Things" at the back of the researcher's mind. It was in this final step that the meanings of the poems can be clustered into three main God's-existencethemes, namely in nature, ourselves, and others as detailed below. 


\section{Results and Discussion}

\section{Finding God in Nature}

The presence of God around us is clearly seen in the works of Robert Francis (19011987), a poet from Upland, Pennsylvania, who was heavily influenced by the more famous contemporary American poet Robert Frost. Written in Frost's freestyle poetry, Francis' "Nothing is Far" tells of the speaker's quest to see God in his everyday life. The poem begins with the description of God whose name is never heard by the song of birds or the rustling of the wind but is truly experienced by the poet. That God is present everywhere is clear here: "Nothing is far that once was near. /Nothing is hid that once was clear. /Nothing was God that is not here." The poem ends with: "Here is the bird, the tree, the stone. /Here in the sun I sit alone. /Between the known and the unknown." Although this vegetarian poet received numerous writing awards during his career, not much is written about Francis except that some liken his works with Emily Dickinson's in terms of the metaphysical presence of God in nature (Nelson, 1977; Shaw, 1993; Stambuk, 1999).

The presence of God in nature is also revealed by several poets from Indonesia. In "Sajak Tentang Kau" [A Poem about You] written by Asep Samboja (1967-2010), the speaker of the poem tries to deny the existence of God but becomes helpless because God is present everywhere. The speaker's attempt to make a poem about "God does not exist" fails because of the continual presence of "ocean foam" and "waves" put off by the "fire of [His] soul" (Samboja, 2006b). Besides, there is always "the roar of Your voice" that the speaker can hear by the sea. The speaker makes his last attempt by burning down his book containing a poem about "God does not exist" only to find that the green grass grows on the ground with burnt ashes, thanks to the rain that comes. Both Samboja and Francis represent anxiety turning into faith about God's presence. No matter how hard we try to deny God's existence or to hide from Him, He is still present, and He stays close to us.

The presence of God in the universe and everything in it is in accordance with the
Spiritual Exercises in Ignatian Spirituality. As explained in the Spiritual Exercises handbook, God created human beings and He continues to be present in us with great love. To welcome God's love, there is nothing more glorious than praising, giving respects, and serving God Himself (Loyola, 1993). The objects around us become touchstones, to borrow Gonzalez's term above (Gonzalez, n.d.) that always make us aware of the presence of God and His immense love. One of the main teachings in Ignatian Spirituality is directing one's life as a living being to conform to God's own purposes and will and thereby praising and glorifying His name (Ad Maiorem Dei Gloriam). Francis and Samboja never saw each other. Poets may see different touchstones at different places and times, but their hearts tremble when they see such diverse creations as wind, waves, birds, rocks, flowers, grass, etc.

\section{Finding God in Ourselves}

That finally God is found in all creations including in the human heart is also proven through Asep Samboja's other poem "Di Masjid Besar" [At the Great Mosque] and "Misal" [If] by Joko Pinurbo. Samboja first asks what flowers mean if they are not sweet-smelling or oysters without pearls in them. This short poem ends with "What am I without You in my pulse?" (Samboja, 2006a). Likewise, in Pinurbo's poetry, God asks "Supposing I come to your house" to someone who is fervently praying. The Lord continues, "Will you come out of your prayer and open the door for Me?" (Pinurbo, 2017, p. 68). There is a certain meaning assigned to the title of this Pinurbo poem written in 2016. The title "Misal" literally means "If". But it sounds like "misa" to the Indonesian ears or "mass/missal" in English, namely a book containing texts used in Mass or Eucharistic Celebration in the Catholic Church throughout the year.

Known for, among others, for his one-line poem entitled "The Night Prayer" where he quips "Dear God, please accept the birdsong in my head", Pinurbo has made use of the Bible as sources of inspiration that never dries up (Pinurbo, 2018, p. 41). In his own acknowledgement, his favorite verse is as follows: "In all things give thanks, for this is what God wanted in Jesus Christ for you." (1 
Thessalonians 5:18). Joko Pinurbo obtains his poetic spirituality from the Spiritual Exercises 23 of the Jesuits. Readers of his poetry can capture with ease and create meaning for the moral messages in his various poems about events or people's daily affairs, God's relationship with humans, and human relations.

Although they come from different religious backgrounds, Samboja and Pinurbo both see the doubts of the religious community when carrying out their worship. Many of us fall into the trap of thinking that the only places to find God are in churches, mosques, and other places of worship. When we do not expect to find God anywhere else except in sacred buildings, we may miss great opportunities to receive comfort and healing as well as spiritual growth from God Himself. In fact, God is so close. The golden quote "God is only as far as prayer" is reflected critically in both "Di Masjid Besar" and "Misal".

At this stage, it can be said that the speaker in each poem finds God through discretion. Discretion is at the heart of Ignatian Spirituality. It is through discretion that we touch the deepest part of ourselves, i.e. the space where God speaks to us. As written in Proverbs 2: 10-11, "For wisdom will enter your heart, and knowledge will be pleasant to your soul; Discretion will protect you, and understanding will guard you." Discretion is not only necessary to solve big problems, but a means of struggle to follow God in a better way over time. Samboja and Pinurbo's works respectively depicts a person who finally found God through a very intimate and personal communication.

The next poem is "Who Hides" written by the Sri Lankan poet and priest Derrick Mendis (1936-2016). "I seek your face with longing heart," says the poet, "Please do not hide, be my guide, with me abide" (Mendis, 2008, p. 38). At this request, God answers, "Through life. I guide you day by day, /Draw you gently, when you stray. /With you, beside you, constantly. /Tis you, my love, who hides from me". In "Who Hides", it is proven that God never hides. Through this poem, the poet attests that God does not need to be sought because we ourselves have often been hiding or avoiding God. For a Jesuit like Mendis, Spiritual Exercise is the breath of daily life. In his obituary Mendis is described as "a servant of the Lord, friend of the poor, fearless poet against the powers-that-be, and, most of all, a humble human being who enjoyed everything and never craved for anything" (Jayawardena, 2017).

The question why humans hide from God seems to be answered by Bakdi Soemanto's poem entitled "Pond". This poem is a monologue of someone who tries to recall the advice given by his lover as they sit together by the pond not to disturb the calm and clear water. The reflection of the sky, leaves, and dust blown away by the wind fall on the pond. The advice continued thus: "Don't disturb, you say /your heart is calm and clear /Behold, you say, /the face of God is reflected /Also the echoes of His word shake the water surface." (Soemanto, 2007, p. 121). The poet welcomes the advice while sighing, "Ah, even our sins /betrayal and our grudges / tear His face." This poem is in tune with Psalm 139: 2 saying "You know when I sit and when I rise; You perceive my thoughts from afar". Even though the poem is multi-interpreted, it captures doubt and regret. God is present in the character's mind when he realizes his past actions that grieve God.

It can be concluded for now that poetry and spiritual life overlap. Spiritual life is concerned with overcoming egoism, pride, prejudice, and so on, including insecure feelings about meeting God. Poetry can be a spiritual practice or a way of life. These findings agree with the claim made by Robert McDowell above that through poetry, peace, and understanding of oneself, others, and the wider world can be obtained (McDowell, 2008). Poetry is a spiritual practice for finding meaning, maturity, and peace.

\section{Finding God in Others}

No poem is more vivid about God's presence in others than the Gospel of Matthew 25: 35-40. These five important verses contain the teachings of love for caring for the sick, visiting the sick in prison, and giving hospitality to strangers. This is the real practice of justice for fellow people as well as a 
testimony to God's presence. It was also mentioned previously in Matthew 18:20, "For where two or three gather in My name, there am I with them." Jesus taught us to love others as we love ourselves.

The theme of "Finding God in Others" often appears in world poetry from time to time. Before discussing the poems chosen in this study, here is an overview of several famous poems that describe the presence of God in other people's life. Mary Dawson Hughes is famous for her description of God's presence in her oft-quoted haiku thus: "The finger of God touches your life when you make a friend." Likewise, the work of the evangelist John Henry Newman is clear: "I sought to hear the voice of God and climbed the topmost steeple, but God declared: 'Go down again - I dwell among the people'." Another example, Father Zosima in Fyodor Dostoevsky's The Brothers Karamazov has this to say: "Love all of God's creation, both the whole and every grain of sand. Love every leaf, every ray of light. Love animals, love plants, love everything." Zosima assured that humans will feel the mystery of God in everything; and once people understand this mystical wisdom, it is not difficult to recognize the value of the whole world with an all-embracing and universal love.

If we believe that humans are created in God's image, the way we learn about God is to live with love for others. In Ignatian Spirituality, "everything which God created out of love, must therefore be used and presented to Him with great respect and love, to glorify God and love others responsibly and not attached to personal ambition". This principle is tallied with the message conveyed by the Christian pastor, writer, and lawyer Lauren Adams in her latest book Parable of the Brown Girl: The Sacred Lives of Girls of Color. Adams's book is about a young woman of color who is often ignored and disrespected, to say nothing of her often-unnoticed opinions in American society in general. Just as Jesus himself taught using many parables, Adams presents girls of color as the main characters in the story in order to interpret their struggles, dreams, hopes, and dignity. It is in these small and marginalized people that the face of God is seen. Among the poems quoted by Adams is
William Blake's famous $18^{\text {th }}$ century English poet "I Sought My God": "I sought my soul /But my soul I could not see /I sought my God /But my God eluded me /I sought my brother /and I found all three." By quoting Blake's poem, Adams wants to show that God created human beings who are different from one another to love one another. Adams picked up the story of weak colored girls who are usually overlooked to show that God has used our weaknesses to prove His power. As Saint Paul told his church in Corinth, "God chose the foolish things of the world to shame the wise; God chose the weak things of the world to shame the strong; God chose the lowly things of this world and the despised things - and the things that are notto nullify the things that are, so that no one may boast before Him." (1 Corinthians 1:2729).

Finally, a poet remembers God as he sees the weak, poor, and suffering in "Easter at Kentucky Fried Chicken". Written by Subagio Sastrowardoyo, a new generation of modern Indonesian poet after the 1945 cohort, this poem tells the story of a person who resolves not to eat fried chicken when he sees a baby crying in the arms of a thin woman who is scavenging a trash can in front of the restaurant. He further says: "The coca-cola burns my throat /when I remembered hollowed faces in the dark, /with a halo of green flies." (Sastrowardoyo, 1990, p. 200). Known for his urban setting, Sastrowardoyo also highlights poverty and injustice that occurred in other parts of the world. Then, like the self-sacrificing Christ, he continues, "Come to me. Cut up my body /and enjoy my flesh the whitest bread/ and my blood - the purest of wines /until there is left only my limp skeleton /drooping on the branch." He ends his poetry thus: Eloi, Eloi, lama sabachtani - My God, my God/ Why hast thou forsaken us?" Even though Sastrowardoyo's poem was written several decades ago, the gap between the rich and the poor is but a grim reality that continues to occur today. Therefore, this poem echoes the Word of God indirectly - I say to you, verily, anything that you did not do for one of the least of these, you did not do it for Me, as scripted in Matthew 25: 46. This is to say that the closer we get to God, the closer we get to our neighbor in need. Therefore, on the basis of this love for others, God has been 
recurrently featured in different poems from different parts of the world.

\section{Conclusion}

Literature reflects human life: success, failure, love, hate, peace, war, forgiveness, and revenge - all unfold imaginatively and creatively. Literary works such as the seven poems discussed here convey noble values in addition to their linguistic and artistic resources like language style, metaphor, symbolism, and many more. Slowly and thoughtfully made, poems have life in them. The poems studied can help us feel God's presence, especially where realities in our lives are not as joyful as we may expect.

This article has shown that the presence of God in nature is a common theme shared by the poets under discussion. God has left His footprints in nature about which the poets marvel. Interestingly, the poets here are not instantly and initially aware of God's presence until nature speaks to them. It is the spiritual connection with nature that the finding of God by each poet is palpably experienced and shared to the reader.

It has also been discussed here that poetry can change one's perspectives in dealing with problems such as doubts about the existence of God, mild spirituality, reluctance to meet God, and other issues of faith. It has also been shown that poetry opens one's heart to love all creations. The speakers in the poems find the presence and call of God in the people and circumstances of their everyday lives as in dating, praying, poetry-writing, having meals, etc. From the three findings about the presence of God in nature, oneself, and fellow humans, it can be concluded that poetry is a prayer and spiritual exercises that can improve people's inner sensitivity and goodness. Thus, the concept of poetry as prayer and divine practice is evident in the selected poems discussed herein. It is also proven that Ignatian Spirituality is a daily spirituality that can be lived by anyone of any national, religious and cultural backgrounds.

\section{References}

Besserman, L., \& Clutterbuck, C. (2007). Encounters with God in Medieval and Early Modern English Poetry. The Sixteenth Century Journal. https://doi.org/10.2307/20478376

Clutterbuck, C. (2018). Finding the Balance in the C-revision of Piers Plowman: FaithGrace-Mercy versus Hope-Works-Justice. In Encounters with God in Medieval and Early Modern English Poetry. https://doi.org/10.4324/978131525653 5-4

George W. Traub (Ed.). (2008). An Ignatian Spirituality Reader. Loyola Press.

Gonzalez, S. (n.d.). Four Hidden Places I've Found Godcom. Ignatian Spirituality.Com, 15 January 2020.

https://www.ignatianspirituality.com/fo ur-hidden-places-ive-found-

god/?utm_source=emagislist\&utm_mediu $\mathrm{m}=$ email\&utm_content $=202001 \& u t$ m_ca mpaign=emagis

Guite, M. (2011). C.S. Lewis: On Both Sides of the Wardrobe. Religious Studies Review. https://doi.org/10.1111/j.17480922.2011.01502.x

Guite, M. (2017a). More than 'a moment's monument.' Book 2.0. https://doi.org/10.1386/btwo.6.1-2.81_1

Guite, M. (2017b). The Word and the Words: In The King James Version at 400. https://doi.org/10.2307/j.ctt5hjgtt.28

Han, C. (2013). Between poetry and philosophy: The Neo-Confucian hermeneutics of Zhu Xi's nine bends poem. Asian Philosophy. https://doi.org/10.1080/09552367.2013 .751748

Hwang, N. M. (2018). In the House of God: Divine Authority and the Collectivity of Spiritual Experience in George Herbert's The Temple and Ralph Vaughan Williams' Five Mystical Songs.

Jayawardena, C. E. (2017, November 11). In memory of Rev. Derrick Mendis. Daily Mirror. http://www.dailymirror.lk/news- 
features/In-memory-of-Rev-DerrickMendis/131-140199

Kubarek, M. (2016). Should the Culture Be Engaged? Modern Islamic Literature and Its Religious and Political Engagement. International Journal of Culture and History (EJournal). https://doi.org/10.18178/ijch.2016.2.1.0 37

Loyola, I. (1993). Latihan Rohani (terjemahan J. Darminta SJ). Penerbit-Percetakan Kanisius.

McDowell, R. (2008). Poetry as Spiritual Practice. Free Press.

McMahon, M. P. (2010). Jesus Christ as The Modern Hero in John Milton's Paradise Lost. Inquiries Journal/Student Pulse, 2.

Mendis, D. (2008). “Who Hides.” In Musings \& Meanderings (p. 38). Carl Fernando.

Nelson, H. (1977). Moving Unnoticed: Notes on Robert Francis's Poetry. Hollins Critic, 14(4), 1.

Neumann, K. (2012). Faith, Hope and Poetry: Theology and the Poetic Imagination. By Malcolm Guite. Literature and Theology. https://doi.org/10.1093/litthe/frs003

Owens, D. C. (2017). Meditations on the Psalms in words and images: an artsintegrated spiritual practice. Journal of Poetry Therapy. https://doi.org/10.1080/08893675.2017 .1351708

Pinurbo, J. (2017). “Misal.” In Buku Latihan Tidur: Kumpulan Puisi Joko Pinurbo (p. 42). GPK.

Pinurbo, J. (2018). Kitab Suci: Inspirasi Menulis Puisi (Bagian 2). Rohani, 02(65), 41.

Richardson, G. (2013). MALCOLM GUITE, Faith, Hope and Poetry: Theology and the Poetic Imagination. Notes and Queries. https://doi.org/10.1093/notesj/gjs243

Samboja, A. (2006a). “Di Masjid Besar.” In Kusampirkan Cintaku di Jemuran (p. 69). bukupop.

Samboja, A. (2006b). "Sajak Tentang Kau." In Kusampirkan Cintaku di Jemuran (p. 68). bukupop.
Sastrowardoyo, S. (1990). Paskah di Kentucky Fried Chicken. In J. H. McGlynn (Ed.), Walking Westward in the Morning: Seven Contemporary Indonesian Poets (p. 201). The Lontar Foundation.

Shaw, R. B. (1993). Reviewed Work: Late Fire, Late Snow: New and Uncollected Poems by Robert Francis. Poetry, 163(1), 39-42.

Shen, V. (2014). Wisdom and hermeneutics of poetry in classical confucianism. In Dao Companion to Classical Confucian Philosophy. https://doi.org/10.1007/978-90-4812936-2_11

Soemanto, B. (2007). “Kolam.” In Kata: Antologi Puisi 1976 - 2006 Bakdi Soemanto (p. 121). Penerbit Bentang.

Spirituality: Finding God in All Things. (n.d.). Jesuits.

https://jesuits.global/en/spirituality\#fin ding-god-in-all-things

Stambuk, A. (1999). Learning to Hover: Robert Frost, Robert Francis, and the Poetry of Detached Engagement. Twentieth Century Literature. https://doi.org/10.2307/441951

Thompson, K. O., \& Wei-Ming, T. (1987). Confucian Thought: Selfhood as Creative Transformation. Philosophy East and West. https://doi.org/10.2307/1398522

Timpane, John. (2001). Poetry for Dummies. Wiley Publishing, Inc.

Twombly, C. C. (2013). Book Review: Faith, Hope and Poetry: Theology and the Poetic Imagination. Christianity \& Literature. https://doi.org/10.1177/014833311306 200212

YAN Xiao-jiang. (2017). Confucianism in Du Fu's Poetry and Sun Dayu's Translation. Journal of Literature and Art Studies. https://doi.org/10.17265/21595836/2017.08.003

YEH, M. (1988). TAOISM AND MODERN CHINESE POETRY. Journal of Chinese Philosophy. https://doi.org/10.1111/j.15406253.1988.tb00596.x 